\title{
Association between metformin use prior to admission and lower mortality in septic adult patients with diabetes mellitus: beware of potential confounders
}

\author{
Patrick M. Honore*, Aude Mugisha, Luc Kugener, Sebastien Redant, Rachid Attou, Andrea Gallerani and \\ David De Bels
}

We read with great interest the recent paper by Liang et al. who conclude that their meta-analysis indicated an association between metformin (MET) use prior to admission and lower mortality in septic adult patients with diabetes mellitus [1]. We would like to make some comments. Nearly half of critically ill patients, especially those with septic shock, have or develop acute kidney injury (AKI), and 20-25\% need renal replacement therapy (RRT) within the first week of their admission [2]. Because of its low molecular weight and minimal protein binding, metformin is equally (highly) eliminated by ultrafiltration (convection) and dialysis (diffusion). Furthermore, its large volume of distribution within a two-compartment pharmacokinetic model implies that metformin may be more effectively cleared by prolonged RRT. This was corroborated by Keller et al., who showed a dramatic reduction of metabolic acidosis and metformin plasma concentrations within the first $24 \mathrm{~h}$ after initiating CRRT in patients with MET-induced lactic acidosis, followed by normalization on the second day in all subjects [3]. Although we do not know the exact rate of CRRT in both arms [1], it may well be that one group had more CRRT than the other, particularly the metformin group. For instance, in the study of Doenyas-Barak et al., which had a huge impact on the conclusions of this meta-analysis, the use of RRT was higher in the MET-treated population (38.6 vs. $21.2 \%, p=0.13$ ) [1, 4]. Accordingly, we suspect that the observed difference in

\footnotetext{
* Correspondence: Patrick.Honore@CHU-Brugmann.be

ICU Department, Centre Hospitalier Universitaire Brugmann-Brugmann

University Hospital, Place Van Gehuchtenplein, 4, 1020 Brussels, Belgium
}

mortality rate may be due to the more frequent use of RRT in the MET-treated population. A protective effect of RRT has already been suggested by Peters et al., who found that despite higher illness severity, the mortality rate in patients with MET-associated lactic acidosis treated with intermittent hemodialysis (IHD) was no different to that of non-dialyzed subjects [5].

\section{Abbreviations \\ MET: Metformin; AKI: Acute kidney injury; RRT: Renal replacement therapy; IHD: Intermittent hemodialysis; CRRT: Continuous renal replacement therapy}

\section{Acknowledgements \\ We would like to thank Dr. Melissa Jackson for critical review of the manuscript.}

\section{Authors' contributions}

$\mathrm{PMH}, \mathrm{SR}$, and DDB designed the paper. All authors participated in drafting and reviewing. The authors read and approved the final version of the manuscript.

\section{Funding}

None.

\section{Availability of data and materials} Not applicable.

\section{Ethics approval and consent to participate} Not applicable.

\section{Consent for publication}

Not applicable.

\section{Competing interests}

The authors declare to have no competing interests. 
Received: 26 March 2020 Accepted: 21 April 2020

Published online: 28 April 2020

\section{References}

1. Liang H, Ding X, Li L, Wang T, Kan Q, Wang L, Sun T. Association of preadmission metformin use and mortality in patients with sepsis and diabetes mellitus: a systematic review and meta-analysis of cohort studies. Crit Care. 2019;23(1):50. https://doi.org/10.1186/s13054-019-2346-4.

2. Peters E, Antonelli M, Wittebole X, Nanchal R, François B, Sakr Y, et al. A worldwide multicentre evaluation of the influence of deterioration or improvement of acute kidney injury on clinical outcome in critically ill patients with and without sepsis at ICU admission: results from The Intensive Care Over Nations audit. Crit Care. 2018;22(1):188. https:/doi.org/ 10.1186/s13054-018-2112-z..

3. Keller G, Cour M, Hernu R, Illinger J, Robert D, Argaud L. Management of metformin-associated lactic acidosis by continuous renal replacement therapy. PLoS One. 2011;6:e23200.

4. Doenyas-Barak K, Beberashvili I, Marcus R, Efrati S. Lactic acidosis and severe septic shock in metformin users: a cohort study. Crit Care. 2016;20:10.

5. Peters N, Jay N, Barraud D, Cravoisy A, Nace L, Bollaert PE, et al. Metforminassociated lactic acidosis in an intensive care unit. Crit Care. 2008;12:R149.

\section{Publisher's Note}

Springer Nature remains neutral with regard to jurisdictional claims in published maps and institutional affiliations. 